\title{
Massey will leave NSF amid controversy over its future
}

\begin{abstract}
Washington. The decision last week by Walter Massey, director of the US National Science Foundation (NSF), to become second-in-command at the University of California (UC) system leaves the Clinton administration with the difficult job of finding someone who can reconcile competing demands on NSF from the politicians who fund it and from the scientists who receive the money.
\end{abstract}

Massey, who has accepted the position of provost and senior vice president for academic affairs at the \$7-billion-a-year, 166,000 -student UC system, joined NSF in March 1991 from the University of Chicago. His appointment is expected to be ratified on 18 February by the UC Board of Regents, and he is expected to leave NSF by the end of March, less than halfway through his six-year term as NSF director.

Massey, 54, is a physicist turned administrator with a reputation for working behind the scenes. Yet his tenure at NSF, which this year will spend $\$ 2$ billion on academic research, was marked by a growing public debate on what role NSF should play in strengthening the US economy. That debate has been sharpened by one of the few promises about research that President Bill Clinton made during his campaign, namely to balance the civilian and military portions of the government's \$75-billion budget for research and development, which now tilts 58:42 towards defence.

Massey waded into that debate last summer by forming a commission to study the future of NSF. His hand was forced by demands from Congress that NSF support more research relevant to industry. Although the commission (see Nature 360, 285; 1992) issued a ringing endorsement of basic research and reinforced previous comments from industrial leaders that NSF should continue to train scientists and not try to pick which technologies have the greatest commercial potential, university researchers were greatly upset that NSF was even thinking about abandoning its original mission.

Such an idea infuriates NSF officials, who insist that Massey never intended to turn away from investigator-initiated basic research. But they are quick to say that NSF must change with the times or risk losing its central role in US science and, more importantly, any hope of a larger budget.

"Two years ago we weren't even thinking about where we were going", says Mary Anne Fox, a professor of chemistry at the University of Texas at Austin and a member of the NSF commission as well as of the National Science Board, the 24-member governing body for NSF. "He recognized

that change was coming and he began to pull the NSF back into line."

But many would disagree, saying instead that Massey has accelerated a shift away from individual researchers and towards large-scale and commercially orientated activities that began under his predecessor, Erich Bloch. What NSF needs, they say, is an eminent scientist with the skills to persuade the public and the politicians of the benefits of basic research. Anything less, they argue, will lead to a further deterioration of an already bad situation in many fields in which hundreds of talented young scientists compete for a single university position and fewer than one in four grant applications are funded.

Massey's departure coincides with the reauthorization this year of legislation that broadly spells out the types of programmes that NSF should be supporting. This exercise, conducted every five years, involves three congressional committees, one in the House of Representatives and two in the Senate (because of overlapping jurisdiction). Their interests, although different, will also influence the continuing debate about NSF's direction.

The topics to be addressed include the health of the research enterprise, in particular whether the system is too large for the funds available; the need for billions of

\section{Italians criticize selection process}

Munich. The new president of Italy's research council (CNR) takes up his position this month amid controversy over the selection process. Microbiologist Enrico Garaci,

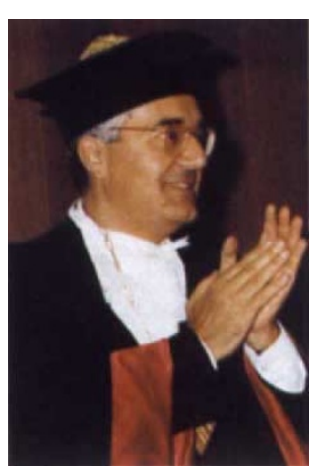

Enrico Garaci currently rector of the Second University of Rome, benefited from the discredited 'Lottizzazione' system, in which positions are divided among the main coalition parties in government. In Garaci's case, the post fell to the Christian Democrats because the minister of research, Sandro Fontana, belongs to that party.

Garaci's appointment comes as public pressure grows to end the Lottizzazione system. Physicist Carlo Bernadini from the University of Rome was the first to speak out publicly against a system that he describes as

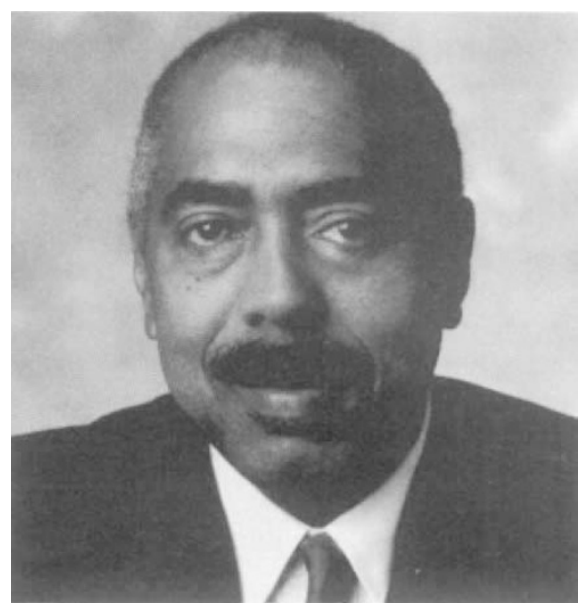

Massey is heading west.

dollars to renovate ageing research facilities on campus; the sorry state of science and mathematics education in elementary and secondary schools; NSF's role in promoting a dozen or more 'critical technologies' and its ability to work more closely with industry on government-funded generic research. The next director will necessarily spend a great deal of time reconciling divergent opinions on these and other issues.

Nevertheless, the job is an attractive one. Because NSF is an independent agency, the director has an opportunity to take his case directly to senior White House staff, including the budget director, and on rare occasion even to the president himself. Vice President $\mathrm{Al}$ Gore and the new science adviser, John Gibbons, are expected to play major roles in the selection process.

Jeffrey Mervis "a clearly illegal procedure which happens in no other democracy". Garaci himself was a victim of Lottizzazione when he stood for election in 1989: although he received the most votes, the Socialists were given the powerful position of Mayor of Rome. As a result, Garaci was owed a favour, which has now been granted.

Despite unhappiness about the system, few criticize his qualifications for the job. $\mathrm{He}$ is familiar with the organization as a scientist and member of one of the CNR's 15 advisory committees (biology and medicine), and his ten years as rector of the Second University of Rome have given him plenty of administrative experience.

Garaci supports the prevailing opinion that Italian science must move away from a system in which state funding is allocated evenly (everyone gets a small grant) and toward a focus on the best research. He believes that the grant reviewing system, currently handled by several advisory committees, should be standardized and that referees from other countries should be used.

Alison Abbott 